\title{
Reproductive tissue selective actions of progesterone receptors
}

\author{
Biserka Mulac-Jericevic and Orla M Conneely \\ Department of Molecular and Cellular Biology, Baylor College of Medicine, 1 Baylor Plaza, Houston, \\ Texas 77030, USA \\ Correspondence should be addressed to O M Conneely; Email: orlac@bcm.tmc.edu
}

\begin{abstract}
The steroid hormone, progesterone, plays a central coordinate role in diverse events associated with female reproduction. In humans and other vertebrates, the biological activity of progesterone is mediated by modulation of the transcriptional activity of two progesterone receptors, PR-A and PR-B. These receptors arise from the same gene and exhibit both overlapping and distinct transcriptional activities in vitro. To delineate the individual roles of PR-A and PR-B in vivo, we have generated mouse models in which expression of a single PR isoform has been ablated. Analysis of the reproductive phenotypes of these mice has indicated that PR-A and PR-B mediate mostly distinct but partially overlapping reproductive responses to progesterone. While selective ablation of the PR-A protein (PR-A knockout mice, PRAKO mice) shows normal mammary gland response to progesterone but severe uterine hyperplasia and ovarian abnormalities, ablation of PR-B protein (PRBKO mice) does not affect biological responses of the ovary or uterus to progesterone but results in reduced pregnancy-associated mammary gland morphogenesis. The distinct tissue-specific reproductive responses to progesterone exhibited by these isoforms are due to regulation of distinct subsets of progesterone-dependent target genes by the individual PR isoforms. This review will summarize our current understanding of the selective contribution of PR isoforms to the cellular and molecular actions of progesterone in reproductive tissues.

Reproduction (2004) 128 139-146
\end{abstract}

\section{Progesterone receptors}

The steroid hormone, progesterone, is a key modulator of normal reproductive functions. These include ovulation, uterine and mammary gland development and the neurobehavioral expression associated with sexual responsiveness (Clarke \& Sutherland 1990, Lydon et al. 1995). The physiological effects of progesterone are mediated by interaction of the hormone with two specific intracellular progesterone receptors (PRs) termed PR-A and PR-B. Progesterone receptors are members of a large family of structurally related gene products known as the nuclear receptor (NR) superfamily (Evans 1988, O'Malley \& Conneely 1992, Tsai \& O'Malley 1994a, Mangelsdorf et al. 1995) of transcription factors. NRs regulate gene transcription by discriminative binding to DNA regulatory sequences as well as by specific interactions with co-activator and/or co-repressor proteins to regulate the activity of the RNA polymerase complex (McKenna \& O'Malley 2001).

PRs are expressed from a single gene as a result of transcription from two alternative promoters (Kastner et al. 1990, Kraus \& Katzenellenbogen 1993) and translation initiation at two alternative AUG initiation codons
(Conneely et al. 1989). The production of these two isoforms is conserved in a number of vertebrate species including humans and rodents (Lessey et al. 1983, Conneely et al. 1989, Shyamala et al. 1990, Giangrande \& McDonnell 1999) and the ratios of the individual isoforms vary in reproductive tissues as a consequence of developmental (Shyamala et al. 1990) and hormonal (Duffy et al. 1997) status and during carcinogenesis (Graham et al. 1996).

Binding of progesterone to PRs induces a significant conformational change on the receptor proteins (Allan et al. 1992a,b) that results in dimerization of two ligand receptor complexes (Tsai et al. 1988, Tsai \& O'Malley 1991), increased receptor phosphorylation (Weigel et al. 1995), binding of receptor dimers to specific hormone responsive DNA elements located in the promoter regions of target genes (Gronemeyer 1991, Tsai \& O'Malley 1994b), and interaction of the receptor complex with specific coactivator proteins and general transcripton factors (Onate et al. 1995, Kamei et al. 1996) to form a productive transcription initiation complex on specific target gene promoters. The overall structural features of the PRs that are responsible for these activities are well defined 
PR-B

\begin{tabular}{|c|c|c|}
\hline AF-3 & AF-1 & \\
\hline ID & DBD & LBD \\
\hline
\end{tabular}

PR-A

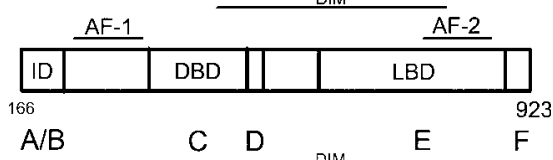

Figure 1 Structural organization of the human PR-A and PR-B isoforms. Numbers denote the amino acid position in each protein. AF-1, AF-2 and AF-3 are activation domains; DBD, DNA binding domain; LBD, ligand binding domain; ID, inhibitory domain; DIM, sequences important for receptor dimerization.

(Fig. 1). The amino terminal or $\mathrm{A} / \mathrm{B}$ region of $\mathrm{PRs}$ is the most hypervariable region in terms of both size and amino acid sequence among members of the superfamily. This region contains transactivation domains (AF- 1 and $\mathrm{AF}-3$ ) that recruit coactivator proteins to the receptor to modulate the level and promoter specificity of target gene activation (Tora et al. 1988, Dobson et al. 1989, Meyer et al. 1992, Sartorius et al. 1994) as well an inhibitory domain (ID) responsible for recruitment of transcriptional inhibitory corepressor proteins (Giangrande et al. 1997). The most conserved region $(\mathrm{C})$ is the DNA binding domain (DBD) that, in the case of PRs, is centrally located. This domain consists of approximately 66-68 amino acids and is composed of two type II zinc finger structures that facilitate binding of the receptor to specific cis-acting DNA sequences and are the hallmark of the nuclear receptor superfamily (Luisi et al. 1991, Freedman 1992). A highly conserved ligand binding domain (LBD) is located on the carboxy terminal side of the DBD. In addition to its progesterone binding function, this region contains an additional transactivation domain (AF-2) required for hormone-dependent coactivator recruitment, sequences important for interaction of inactive receptors with heat shock proteins and for receptor dimerization (DIM) (Pratt et al. 1988, Webster et al. 1988, Fawell et al. 1990, Vegeto et al. 1992).

In the early 1990s, in vitro biochemical studies revealed that the two PR isoforms displayed quite distinct transactivational properties that are specific to both the cell type and the target gene promoter used (Tora et al. 1988, Meyer et al. 1992, Vegeto et al. 1993, Hovland et al. 1998). Specifically, PR-B has been shown to function as a strong activator of transcription of several PR-dependent promoters and in a variety of cell types in which PR-A is inactive. In addition, when the PR-A and PR-B proteins are co-expressed in cultured cells, the PR-A can repress the activity of PR-B as well as the activity of other nuclear receptors (Giangrande \& McDonnell 1999). Further, the PR-A and PR-B proteins also respond differently to progesterone antagonists (reviewed in Giangrande \& McDonnell 1999). While antagonist bound PR-A is inactive, antagonist bound PR-B can be converted to a strongly active transcription factor. When expressed in equimolar ratios in cells, the PR-A and PR-B proteins can dimerize and bind DNA as three distinct species: A:A or B:B homodimers or $\mathrm{A}: \mathrm{B}$ heterodimers. The differential transactivation properties contributed to these complexes by the presence or absence of the PR-B-specific AF-3 domain is likely to contribute to the complete repertoire of physiological responses to progesterone.

While it is well established that PRs mediate the transcription regulatory effects of progesterone, the signal transduction properties of PRs are not restricted to respond to their steroidal ligand. Studies using tissue culture systems have revealed that PRs as well as some other nuclear receptors can be activated in a ligand-independent manner by stimuli that modulate intracellular kinase activity (Denner et al. 1990, Aronica \& Katzenellenbogen 1991, 1993, Beck et al. 1993, Sartorius et al. 1993). The physiological relevance of a progesterone-independent mechanism of receptor activation has been substantiated in vivo: PR-mediated lordosis behavior exhibited by rats (Mani et al. 2001) and mice (Mani et al. 1996) can be stimulated either in response to progesterone or in the absence of progesterone by dopamine-activated intracellular signaling pathways.

In addition to its PR-mediated genomic actions, progesterone also stimulates cellular responses that are independent of the transcription regulatory function of PRs by at least two distinct mechanisms. The first is PR dependent and involves PR-mediated activation of intracellular phosphorylation cascades, at least one of which is the Src/Ras/ MAP kinase pathway, to modulate cellular responses to the hormone (Boonyaratanakornkit et al. 2001, Ballare et al. 2003). The second mechanism is independent of PRs and appears to be mediated by interactions with specific membrane receptors for progesterone. Plasma membraneassociated progesterone-specific receptors have been isolated and cloned from a range of tissues and from a number of species (Bramley 2003) and are identified as $G$ protein-coupled receptors distinct from classical intracellular PRs (Zhu et al. 2003). Rapid non-genomic effects of progesterone have been implicated in modulation of the sperm acrosome reaction (Bronson et al. 1999, Patrat et al. 2000), modulation of neuronal excitability (Genazzani et al. 2000, Lambert et al. 2003), prevention of preterm labor (Grazzini et al. 1998), and Xenopus oocyte maturation (Bayaa et al. 2000). While several of these responses appear to be regulated in a PR-independent manner, the contribution of PR-mediated non-genomic signaling to the physiological activities of progesterone remains poorly understood.

\section{Progesterone receptor knockout (PRKO) models demonstrate tissue specific roles of PRs in reproductive tissues}

Phenotypic studies of the PRKO mouse model in which the expression of both isoforms was inhibited by null mutation of the PR gene provided compelling evidence of 
an essential role of PRs in all aspects of female reproduction. Specifically, female mice lacking both PRs exhibit impaired sexual behavior and neuroendocrine gonadotropin regulation, anovulation, uterine dysfunction and impaired pregnancy-associated mammary gland morphogenesis (Lydon et al. 1995, Mani et al. 1996, Chappell et al. 1999, Tibbetts et al. 1999). Furthermore, studies of the PRKO mouse reveal that PRs also play an essential role in regulation of thymic involution during pregnancy (Tibbetts et al. 1999) and in the cardiovascular system through regulation of endothelial and vascular smooth muscle cell proliferation and response to vascular injury (Vazquez et al. 1999).

The differences in transcriptional activities and coregulator interactions between the PR-A and PR-B observed in vitro predicted that these proteins may mediate different physiological responses to progesterone. In addition, the selective ability of PR-A to inhibit transcriptional responses induced by both PR-B and the estrogen receptors suggested that PR-A has the capacity to diminish overall progesterone responsiveness in certain tissues as well as contribute to the antiestrogenic activities of progesterone previously observed in the uterus (Lydon et al. 1995). However, physiological validation of the functional differences between the PR-A and PR-B isoforms has been hampered due to a lack of information on the specific cell types that express each isoform in vivo and a lack of appropriate animal models in which to dissect their selective functions.

The observation that PR-A and PR-B are produced by translation at two distinct AUG signals encoded by a single gene predicted that mutation of either ATG codon in the PR gene would result in selective ablation of expression of a single isoform in vivo (Conneely et al. 1989, Kastner et al. 1990). Thus, the CRE-loxP gene targeting approach in embryonic stem cells was used to introduce a point mutation into the PR gene at the ATG codon encoding Met 1 (M1L) in order to specifically ablate expression of the PR-B protein, and at the ATG encoding Met 166 (M166A) in order to ablate expression of PR-A (Mulac-Jericevic et al. 2000, 2003). This strategy has provided a powerful model system to examine the selective expression of each isoform in situ as well as to assess the selective contributions of PR-A and PR-B in their normal cellular context to the physiological functions of progesterone.

\section{PRs and ovarian function}

Luteinizing hormone $(\mathrm{LH})$, the primary signal for rupture of preovulatory ovarian follicles leading to ovulation, stimulates transient expression of PR mRNA and proteins in granulosa cells (Natraj \& Richards 1993, Park-Sarge \& Mayo 1994) and the antiprogestin, RU486, inhibits ovulation (Loutradis et al. 1991). Definitive proof that PRs are essential mediators of ovulation has been provided by analysis of the ovarian phenotype of the PRKO mouse. Analysis of this model revealed that PRs are required specifically for LH-dependent follicular rupture leading to ovulation but not for differentiation of granulosa cells to form a corpus luteum (luteinization) (Lydon et al. 1995). Follicular rupture requires induction of a prostaglandinmediated inflammatory response to $\mathrm{LH}$ as well as tissue degradation at the apex of the preovulatory follicle, an event that is mediated by matrix proteinases (Espey 1994). Analysis of the expression of potential mediators of ovulation in PRKO mice has demonstrated that LH-induced regulation of Cox-2, an enzyme that catalyses the production of prostaglandins and is essential for ovulation, is unaffected (Robker et al. 2000). In contrast, the expression of two metalloproteinases, ADAMTS- 1 (a desintegrin and metalloproteinase with thrombospondin motifs) and cathepsin-L (a lysosomal cysteine protease) is inhibited in mural granulosa cells of the mature follicle (Tetel et al. 1999, Robker et al. 2000) in PRKO mice. One of these proteases, ADAMTS-1, is essential for ovulation (Robker et al. 2000) suggesting that this protein may represent a critical mediator of the progesterone-induced ovulatory event.

Both the PR-A and PR-B proteins are induced in preovulatory follicles in response to LH stimulation (Natraj \& Richards 1993). Analysis of PRAKO mice, in which PR-A is ablated, showed that ovulation is severely impaired but unlike in PRKO mice, is not completely absent (Mulac-Jericevic et al. 2000). Histological analysis of the ovaries of PRAKO mice showed numerous mature anovulatory follicles that contained an intact oocyte and were arrested at a similar stage to that previously observed in PRKO mice. In contrast, ovulation is unaffected in PRBKO mice indicating that PR-A expression is both necessary and sufficient to mediate the ovulatory response to progesterone (Mulac-Jericevic et al. 2003). The ovulatory defects in PRAKO mice must therefore be due to an inability of PR-B to regulate signaling pathways necessary for follicular rupture that are as yet unidentified. The observation that the PR-A and PR-B proteins are not functionally redundant in the ovary provides physiological validation of previous studies in tissue culture demonstrating that these transcription factors have different functional activities. From a mechanistic standpoint, the observation that PR-A alone is sufficient to support normal ovulation indicates that heterodimeric interactions between the PR-A and PR-B proteins are not required for regulation of essential progestin-responsive target genes associated with ovulation. With the exception of the above-mentioned proteases, the PR-dependent signaling pathways that mediate follicular rupture have not yet been elucidated. Because the PRKO mouse has a specific defect in follicular rupture while luteinization is maintained, differential array analysis using this model provides an excellent system to delineate the signaling pathways regulated by PRs that are specific to follicular rupture. The identification of these genes should facilitate the identification of PR isoform 
selective target genes that are essential for ovulation, in addition to providing important new information on the molecular mechanisms of progesterone-induced follicular rupture.

\section{PRs and uterine function}

Progesterone plays a critical role during early pregnancy in preparation of the uterine epithelium for receptivity and in differentiation of endometrial stromal cells to a decidual phenotype that supports the development of the implanting embryo. Furthermore, progesterone is a potent antagonist of estrogen-induced proliferation in the uterine epithelium.

The uterus of PRKO mouse fails to support implantation after embryo transfer and is unresponsive to a decidual stimulus (Lydon et al. 1995). In PRKO mice, epithelial cells in the uterus become hyperplastic as a result of unopposed proliferative estrogen action. PRs are expressed in the epithelial, stromal and myometrial compartments of the uterus and their spatiotemporal expression within these compartments is regulated by both estrogen and progesterone (Tibbetts et al. 1998) and undergoes dynamic changes during the estrous cycle and early pregnancy (Tan et al. 1999). This intercompartmental regulation of $\mathrm{PR}$ expression is essential for the appropriate regulation of uterine gene expression (Kurita et al. 1998). Recent analysis of the effects of PR ablation on the expression of several genes previously implicated in progesterone-dependent uterine implantation have shown that the defects observed in PRKO mice are associated with inhibition of expression of several epithelial markers of uterine receptivity (Mulac-Jericevic et al. 2000) and at least one essential stromal mediator of decidualization, hoxa-10 (Lim et al. 1999).

Analysis of progesterone-dependent uterine function in PRAKO and PRBKO mice has revealed that PR-A and PR-B have distinct functions in the uterus (Mulac-Jericevic et al. 2000, 2003). In PRAKO mice, progesterone-induced differentiation of endometrial stromal cells to a decidual phenotype is inhibited, suggesting that PR-A plays a crucial role in decidualization of the stroma prior to implantation (Mulac-Jericevic et al. 2000). In contrast, analysis of uterine function in PRBKO mice has shown that expression of PR-A is both necessary and sufficient to mediate both the antiproliferative- and implantationassociated responses to progesterone (Mulac-Jericevic et al. 2003). The uterine defects observed in PRAKO mice are due to an inability of PR-B to regulate a subset of PRdependent target genes rather than to differences in the spatiotemporal expression of PR-A relative to PR-B in the uterus (Mulac-Jericevic et al. 2000).

Surprisingly, selective activation of PR-B in the uterus of PRAKO mice resulted in an abnormal progesterone-dependent induction of epithelial cell proliferation in contrast to its ability to inhibit estrogen-induced proliferation in the wild-type uterus (Mulac-Jericevic et al. 2000). This gain of
PR-B-dependent proliferative activity upon removal of PR-A indicates that PR-A is required not only to inhibit estrogen-induced hyperplasia of the uterus but also to limit potentially adverse proliferative effects of the PR-B protein.

In the human endometrium, the levels of PR-A and PR-B are differentially regulated during the reproductive cycle (Mangal et al. 1997, Mote et al. 2000). The physiological importance of maintaining the correct relative expression levels of PR isoforms in the uterus is indicated by the identification of aberrant ratios of PR isoforms in human endometrial cancers and the recent identification of a functional polymorphism in the human PR promoter that results in increased expression of the human PR-B isoform and is associated with increased risk of endometrial cancer (Arnett-Mansfield et al. 2001, De Vivo et al. 2002). Given the opposing effects of the PR isoforms in the uterus, one could predict that aberrant changes in the relative spatiotemporal expression patterns of PR isoforms in the uterus could play an important role in determining appropriate responsiveness to progestin therapy in the treatment of uterine epithelial hyperplasias.

\section{PRs and mammary gland morphogenesis}

Mammary gland development is predominantly postnatal and is controlled by a complex interplay of endocrine hormones, in particular estrogen, progesterone and prolactin, acting together with locally acting growth factors (Anderson 2002, Soyal et al. 2002). Postnatal mammary gland development involves two distinct growth phases that are initiated at the onset of puberty and pregnancy respectively. At puberty, estrogen promotes ductal elongation and dichotomous branching to the limits of the mammary fat pad. At adulthood, the virgin gland becomes relatively quiescent with the exception of minimal side branching and alveolar budding that occur over time as a result of the cyclic rise of ovarian steroids during the estrous cycle. At pregnancy, exposure to progesterone and prolactin (PRL) results in extensive epithelial proliferation, increased dichotomous side branching and differentiation of milk-filled alveolar lobules. At weaning, removal of the suckling stimulus elicits involution of the lobular alveolar system through apoptosis and matrix degrading proteinase-mediated remodeling. At the end of the involution process, the postnatal developmental cycle of mammary gland development is completed and the mammary gland resembles the general architecture of the pre-pregnant mammary gland (Anderson 2002, Soyal et al. 2002).

Null mutation of both PR isoforms in PRKO mice has demonstrated that PRs are specifically required for pregnancy-associated ductal proliferation and lobuloalveolar differentiation of the mammary epithelium. Mammary glands of PRKO mice failed to develop the pregnancyassociated side-branching of the ductal epithelium with attendant lobular alveolar differentiation despite normal postpubertal mammary gland morphogenesis of the virgin 
Table 1 Components of female reproductive system and phenotype identified in progesterone receptor knockout mouse models.

\begin{tabular}{lll}
\hline Component & Genotype & Phenotype \\
\hline Ovaries & PRKO & Inability to ovulate \\
& PRAKO & Severely impaired ovulation \\
& PRBKO & Normal ovulation \\
Uterus & PRKO & Impaired implantation/decidualization/infertility \\
& PRAKO & Impaired implantation/decidualization/infertility \\
& PRBKO & Normal implantation/decidualization \\
Mammary gland & PRKO & Impaired mammary gland development \\
& PRAKO & Normal progesterone-induced mammary gland morphogenesis \\
& PRBKO & Reduced pregnancy-associated side-branching and lobuloalveolar development \\
\hline
\end{tabular}

mice (Lydon et al. 1995, Seagroves et al. 2000). Thus, in contrast to its antiproliferative role in the uterus, progesterone is an essential pregnancy-associated proliferative stimulus in the mammary gland.

PRs are expressed exclusively in the mammary epithelium (Seagroves et al. 2000, Sivaraman et al. 2001, Ismail et al. 2002) and development of the mammary gland from juvenile to adult state is associated with a change in the pattern of expression of PRs from a uniform to a scattered pattern of expression in a subset of epithelial cells (Seagroves et al. 2000, Grimm et al. 2002). Recent studies have shown that PR-expressing cells are segregated from proliferating cells in the normal mammary glands of both rodents and humans (Clarke et al. 1997, Seagroves et al. 2000, Ismail et al. 2002). Consistent with this finding, the proliferative responses of the ductal and alveolar epithelium to progesterone are associated with local induction of PR-dependent growth factors that act in a paracrine manner on PR-negative cells to control their proliferation (Brisken et al. 1998, 2000). In contrast to the normal mammary gland, segregation of the steroid receptor expressing cells from proliferating cells is lost in mammary epithelial cells that have been exposed to carcinogen (Sivaraman et al. 2001) and in cells of breast tumors (Graham \& Clarke 2002). This aberrant change in pattern of receptor expression is likely to contribute to abnormal growth of breast cancer cells.

Both isoforms of PR are expressed in the mammary gland of the virgin mouse (Shyamala et al. 1990) and during pregnancy (Fantl et al. 1999) and the levels of PR-A protein exceed those of the PR-B isoform. Progesterone-activated PR-B in PRAKO mice elicits side branching and lobular alveolar development in the mammary gland comparable to that of wild-type mammary gland (MulacJericevic et al. 2000). Thus, PR-B is sufficient to elicit normal proliferation and differentiation of the mammary epithelium in response to progesterone and neither process appears to require functional expression of the PR-A protein. In contrast, recent analysis of the mammary glands of PRBKO mice has shown reduced pregnancy-associated ductal side branching and lobuloalveolar development as a consequence of decreased ductal and alveolar epithelial cell proliferation and increased apoptosis of alveolar epithelium (Mulac-Jericevic et al. 2003). Despite these defects, PR-A retains its normal segregated spatiotemporal pattern relative to proliferating cells in PRBKO mice and is expressed at a higher level than that observed for PR-B in PRAKO mice. Examination of the molecular genetic signaling pathways that are differentially regulated by PRs in the mammary gland showed that the defects observed in PRBKO mice are associated with a PR-B isoform-selective regulation of the receptor activator of nuclear factor kappa B (NFKB) ligand (RANKL) signaling pathway (Mulac-Jericevic et al. 2003) which is essential for alveologenesis (Fata et al. 2000). In contrast, progesteronedependent activation of secreted growth factor, wnt4, a key mediator of branching morphogenesis (Brisken et al. 2000), is normally regulated by either PR-A or PR-B (Mulac-Jericevic et al. 2003). Thus PR-A and PR-B appear to regulate both overlapping and distinct subsets of progesterone-dependent signaling pathways required for mammary gland development.

\section{Conclusion}

Analysis of the phenotypic consequences of selective ablation of the PR-A or PR-B isoforms in mice has facilitated a comprehensive analysis of the selective spatiotemporal expression of these receptors in the reproductive tract and mammary gland as well as elucidation of their individual contributions to the established reproductive activities of progesterone. These studies have revealed that PR-A and PR-B exhibit mostly distinct but partially overlapping hormonal responses (Table 1). PR-A activation is both necessary and sufficient for establishment and maintenance of pregnancy but elicits reduced mammary gland morphogenic responses to hormonal stimulation relative to $\mathrm{PR}-\mathrm{B}$. In contrast, $\mathrm{PR}-\mathrm{B}$ activation is insufficient to support female fertility but is a potent proliferative mediator in the mammary gland and, most surprisingly, in the uterus. The distinct tissue-selective activities of PR-A and PR-B observed in vivo in these studies support the conclusion that modulation of PR activity using isoform-selective progestins may contribute towards elimination of adverse tissue-specific side effects of progestins. 


\section{References}

Allan GF, Leng X, Tsai SY, Weigel NL, Edwards DP, Tsai MJ \& O'Malley BW 1992a Hormone and antihormone induce distinct conformational changes which are central to steroid receptor activation. Journal of Biological Chemistry 267 19513-19520.

Allan GF, Tsai S, Tsai M-J \& O'Malley BW $1992 b$ Ligand-dependent conformational changes in the progesterone receptor are necessary for events that follow DNA binding. PNAS 89 11750-11754.

Anderson E 2002 The role of oestrogen and progesterone receptors in human mammary development and tumorigenesis. Breast Cancer Research 4 197-201.

Arnett-Mansfield RL, deFazio A, Wain GV, Jaworski RC, Byth K, Mote PA \& Clarke CL 2001 Relative expression of progesterone receptors $\mathrm{A}$ and $\mathrm{B}$ in endometrioid cancers of the endometrium. Cancer Research 61 4576-4582.

Aronica SM \& Katzenellenbogen BS 1991 Progesterone receptor regulation in uterine cells: stimulation by estrogen, cyclic adenosine $3^{\prime}, 5^{\prime}$-monophosphate and insulin-like growth factor I and suppression by antiestrogens and protein kinase inhibitors. Endocrinology 128 2045-2052.

Aronica SM \& Katzenellenbogen BS 1993 Stimulation of estrogen receptor-mediated transcription and alteration in the phosphorylation state of the rat uterine estrogen receptor by estrogen, cyclic adenosine monophosphate and insulin-like growth factor-l. Molecular Endocrinology 7 743-752.

Ballare C, Uhrig M, Bechtold T, Sancho E, Di Domenico M, Migliaccio A, Auricchio F \& Beato M 2003 Two domains of the progesterone receptor interact with the estrogen receptor and are required for progesterone activation of the c-Src/Erk pathway in mammalian cells. Molecular and Cellular Biology 23 1994-2008.

Bayaa M, Booth RA, Sheng Y \& Liu XJ 2000 The classical progesterone receptor mediates Xenopus oocyte maturation through a nongenomic mechanism. PNAS 97 12607-12612.

Beck CA, Weigel NL, Moyer ML, Nordeen SK \& Edwards DP 1993 The progesterone antagonist RU486 acquired agonist activity upon stimulation of CAMP signaling pathways. PNAS 90 4441-4445.

Boonyaratanakornkit V, Scott MP, Ribon V, Sherman L, Anderson SM, Maller JL, Miller WT \& Edwards DP 2001 Progesterone receptor contains a proline-rich motif that directly interacts with $\mathrm{SH} 3$ domains and activates c-Src family tyrosine kinases. Molecular Cell 8 269-280.

Bramley T 2003 Non-genomic progesterone receptors in the mammalian ovary: some unresolved issues. Reproduction 125 3-15.

Brisken C, Park S, Vass T, Lydon JP, O'Malley BW \& Weinberg RA 1998 A paracrine role for the epithelial progesterone receptor in mammary gland development. PNAS 95 5076-5081.

Brisken C, Heineman A, Chavarria T, Elenbaas B, Tan J, Dey SK, McMahon JA, McMahon AP \& Weinberg RA 2000 Essential function of Wnt-4 in mammary gland development downstream of progesterone signaling. Genes and Development 14 650-654.

Bronson RA, Peresleni T \& Golightly M 1999 Progesterone promotes the acrosome reaction in capacitated human spermatozoa as judged by flow cytometry and CD46 staining. Molecular Human Reproduction 5 507-512

Chappell P, Schneider JS, Kim P, Xu M, Lydon JP, O'Malley BW \& Levine JE 1999 Absence of gonadotropin surges and gonadotropinreleasing hormone self-priming in ovariectomized (ovx), estrogen (E2)-treated, progesterone receptor knockout (PRKO) mice. Endocrinology $1403653-3658$.

Clarke CL \& Sutherland RL 1990 Progestin regulation of cellular proliferation. Endocrine Reviews 11 266-300.

Clarke RB, Howell A, Potten CS \& Anderson E 1997 Dissociation between steroid receptor expression and cell proliferation in the human breast. Cancer Research 57 4987-4991.
Conneely OM, Kettelberger DM, Tsai M-J, Schrader WT \& O'Malley BW 1989 The chicken progesterone receptor A and B isoforms are products of an alternate translation initiation event. Journal of Biological Chemistry 264 14062-14064.

De Vivo I, Huggins GS, Hankinson SE, Lescault PJ, Boezen M, Colditz GA \& Hunter DJ 2002 A functional polymorphism in the promoter of the progesterone receptor gene associated with endometrial cancer risk. PNAS 99 12263-12268.

Denner LA, Weigel NL, Maxwell BL, Schrader WT \& O'Malley BW 1990 Regulation of progesterone receptor-mediated transcription by phosphorylation. Science 250 1740-1743.

Dobson AD, Conneely OM, Beattie WG, Maxwell BL, Mak P, Tsai M-J, Schrader WT \& O'Malley BW 1989 Mutational analysis of the chicken progesterone receptor. Journal of Biological Chemistry 264 4207-4211.

Duffy DM, Wells TR, Haluska GJ \& Stouffer RL 1997 The ratio of progesterone receptor isoforms changes in the monkey corpus luteum during the luteal phase of the menstrual cycle. Biology of Reproduction 57 693-699.

Espey LL 1994 Current status of the hypothesis that mammalian ovulation is comparable to an inflammatory reaction. Biology of Reproduction $\mathbf{5 0} 233-238$.

Evans RM 1988 The steroid and thyroid hormone receptor superfamily. Science $240889-895$.

Fantl V, Edwards PAW, Steel JH, Vonderhaar BK \& Dickson C 1999 Impaired mammary gland development in $\mathrm{Cyl}^{-1^{-1-}}$ mice during pregnancy and lactation is epithelial cell autonomous. Developmental Biology 212 1-11.

Fata JE, Kong YY, Li J, Sasaki T, Irie-Sasaki J, Moorehead RA, Elliott R, Scully S, Voura EB \& Lacey DL et al. 2000 The osteoclast differentiation factor osteoprotegerin-ligand is essential for mammary gland development. Cell 103 41-50.

Fawell SE, Lees JA, White R \& Parker MG 1990 Characterization and colocalization of steroid binding and dimerization activities in the mouse estrogen receptor. Cell 60 953-962.

Freedman LP 1992 Anatomy of the steroid receptor zinc finger region. Endocrine Reviews 13 129-145.

Genazzani AR, Stomati M, Morittu A, Bernardi F, Monteleone P, Casarosa E, Gallo R, Salvestroni C \& Luisi M 2000 Progesterone, progestagens and the central nervous system. Human Reproduction 15 Suppl 1 14-27.

Giangrande PH \& McDonnell DP 1999 The A and B isoforms of the human progesterone receptor: two functionally different transcription factors encoded by a single gene. Recent Progress in Hormone Research 54 291-313.

Giangrande PH, Pollio G \& McDonnell DP 1997 Mapping and characterization of the functional domains responsible for the differential activity of the $\mathrm{A}$ and $\mathrm{B}$ isoforms of the human progesterone receptor. Journal of Biological Chemistry 272 32889-32900.

Graham JD \& Clarke CL 2002 Progesterone receptors - animal models and cell signaling in breast cancer: expression and transcriptional activity of progesterone receptor $\mathrm{A}$ and progesterone receptor B in mammalian cells. Breast Cancer Research 4 187-190.

Graham JD, Yeates C, Balleine RL, Harvey SS, Milliken JS, Bilous AM \& Clarke CL 1996 Progesterone receptor A and B protein expression in human breast cancer. Journal of Steroid Biochemistry and Molecular Biology 56 93-98.

Grazzini E, Guillon G, Mouillac B \& Zingg HH 1998 Inhibition of oxytocin receptor function by direct binding of progesterone. Nature 392 509-512.

Grimm SL, Seagroves TN, Kabotyanski EB, Hovey RC, Vonderhaar BK, Lydon JP, Miyoshi K, Hennighausen L, Ormandy CJ \& Lee AV et al. 2002 Disruption of steroid and prolactin receptor patterning in the mammary gland correlates with a block in lobuloalveolar development. Molecular Endocrinology 16 2675-2691.

Gronemeyer H 1991 Transcription activation by estrogen and progesterone receptors. Annual Review of Genetics 25 89-123. 
Hovland AR, Powell RL, Takimoto GS, Tung L \& Horwitz KB 1998 An N-terminal inhibitory function, IF, suppresses transcription by the A-isoform but not the B-isoform of human progesterone receptors. Journal of Biological Chemistry 273 5455-5460.

Ismail PM, Li J, DeMayo FJ, O'Malley BW \& Lydon JP 2002 A novel LacZ reporter mouse reveals complex regulation of the progesterone receptor promoter during mammary gland development. Molecular Endocrinology 16 2475-2489.

Kamei Y, Xu L, Heinzel T, Torchia J, Kurokawa R, Gloss B, Lin SC, Heyman RA, Rose DW, Glass CK \& Rosenfeld MG 1996 A CBP integrator complex mediates transcriptional activation and AP-1 inhibition by nuclear receptors. Cell 85 403-414.

Kastner P, Krust A, Turcotte B, Strupp U, Tora L, Gronemeyer H \& Chambon P 1990 Two distinct estrogen-regulated promoters generate transcripts encoding the two functionally different human progesterone receptor forms $\mathrm{A}$ and $\mathrm{B}$. The $E M B O$ Journal 9 $1603-1614$.

Kraus WL \& Katzenellenbogen BS 1993 Regulation of progesterone receptor gene expression and growth in the rat uterus: modulation of estrogen actions by progesterone and sex steroid hormone antagonists. Endocrinology 132 2371-2379.

Kurita T, Young P, Brody JR, Lydon JP, O'Malley BW \& Cunha GR 1998 Stromal progesterone receptors mediate the inhibitory effects of progesterone on estrogen-induced uterine epithelial cell deoxyribonucleic acid synthesis. Endocrinology 139 4708-4713.

Lambert JJ, Belelli D, Peden DR, Vardy AW \& Peters JA 2003 Neurosteroid modulation of GABAA receptors. Progress in Neurobiology $7167-80$.

Lessey BA, Alexander PS \& Horwitz KB 1983 The subunit structure of human breast cancer progesterone receptors: characterization by chromatography and photoaffinity labeling. Endocrinology 112 1267-1274.

Lim H, Ma L, Ma WG, Maas RL \& Dey SK 1999 Hoxa-10 regulates uterine stromal cell responsiveness to progesterone during implantation and decidualization in the mouse. Molecular Endocrinology 13 1005-1017.

Loutradis D, Bletsa R, Aravantinos L, Kallianidis K, Michalas S \& Psychoyos A 1991 Preovulatory effects of the progesterone antagonist mifepristone (RU486) in mice. Human Reproduction 6 $1238-1240$

Luisi BF, Xu WX, Otwinowski Z, Freedman LP, Yamamoto KR \& Sigler PB 1991 Crystallographic analysis of the interaction of the glucocortioid receptor with DNA. Nature 352 497-505.

Lydon JP, DeMayo FJ, Funk CR, Mani SK, Hughes AR, Montgomery CA Jr, Shyamala G, Conneely OM \& O'Malley BW 1995 Mice lacking progesterone receptors exhibit pleiotropic reproductive abnormalities. Genes and Development 9 2266-2278.

McKenna NJ \& O'Malley BW 2001 Nuclear receptors, coregulators, ligands and selective receptor modulators: making sense of the patchwork quilt. Annals of the New York Academy of Sciences $9493-5$.

Mangal RK, Wiehle RD, Poindexter AN 3rd \& Weigel NL 1997 Differential expression of uterine progesterone receptor forms A and B during the menstrual cycle. Journal of Steroid Biochemistry and Molecular Biology 63 195-202.

Mangelsdorf DJ, Thummel C, Beato M, Herrlich G, Schutz G, Umesono K, Blumberg B, Kastner P, Mark M, Chambon P \& Evans RM 1995 The nuclear receptor superfamily: the second decade. Cell 83 835-839.

Mani SK, Allen JMC, Lydon JP, Mulac-Jericevic B, Blaustein JD, DeMayo FJ, Conneely OM \& O'Malley BW 1996 Dopamine requires the unoccupied progesterone receptor to induce sexual behavior in mice. Molecular Endocrinology 10 1728-1737.

Mani SK, Mitchell A \& O'Malley BW 2001 Progesterone receptor and dopamine receptors are required in Delta 9-tetrahydrocannabinol modulation of sexual receptivity in female rats. PNAS 98 1249-1254.

Meyer ME, Quirin-Stricker C, Lerouge T, Bocquel MT \& Gronemeyer H 1992 A limiting factor mediates the differential activation of pro- moters by the human progesterone receptor isoforms. Journal of Biological Chemistry 267 10882-10887.

Mote PA, Balleine RL, McGowan EM \& Clarke CL 2000 Heterogeneity of progesterone receptors $\mathrm{A}$ and $\mathrm{B}$ expression in human endometrial glands and stroma. Human Reproduction 15 Suppl 3 48-56.

Mulac-Jericevic B, Mullinax RA, DeMayo FJ, Lydon JP \& Conneely OM 2000 Subgroup of reproductive functions of progesterone mediated by progesterone receptor-B isoform. Science 289 $1751-1754$.

Mulac-Jericevic B, Lydon JP, DeMayo FJ \& Conneely OM 2003 Defective mammary gland morphogenesis in mice lacking the progesterone receptor B isoform. PNAS 100 9744-9749.

Natraj U \& Richards JS 1993 Hormonal regulation, localization and functional activity of the progesterone receptor in granulosa cells of rat preovulatory follicles. Endocrinology 133 761-769.

O'Malley BW \& Conneely OM 1992 Orphan receptors: in search of a unifying hypothesis for activation. Molecular Endocrinology 6 $1359-1361$

Onate SA, Tsai SY, Tsai MJ \& O'Malley BW 1995 Sequence and characterization of a coactivator for the steroid hormone receptor superfamily. Science 270 1354-1357.

Park-Sarge OK \& Mayo KE 1994 Regulation of progesterone receptor gene by gonadotropins and cyclic adenosine $3^{\prime}, 5^{\prime}$-monophosphate in rat granulosa. Endocrinology 134 709-718.

Patrat C, Serres C \& Jouannet P 2000 The acrosome reaction in human spermatozoa. Biology of the Cell 92 255-266.

Pratt WB, Jolly DJ, Pratt DV, Hollenberg SM, Giguere V, Cadepond F, Schweizer-Groyer G, Catelli MG, Evans RM \& Baulieu EE 1988 $A$ region in the steroid binding domain determines formation of the non-DNA binding 95 glucocorticoid receptor complex. Journal of Biological Chemistry 263 267-273.

Robker RL, Russell DL, Espey LL, Lydon JP, O'Malley BW \& Richards JS 2000 Progesterone-regulated genes in the ovulation process: ADAMTS-1 and cathepsin L proteases. PNAS 97 4689-4694.

Sartorius CA, Tung L, Takimoto GS \& Horwitz KB 1993 Antagonistoccupied human progesterone receptors bound to DNA are functionally switched to transcriptional agonists by cAMP. Journal of Biological Chemistry $2689262-9266$.

Sartorius CA, Melville MY, Hovland AR, Tung L, Takimoto GS \& Horwitz KB 1994 A third transactivation function (AF3) of human progesterone receptors located in the unique $\mathrm{N}$-terminal segment of the B-isoform. Molecular Endocrinology 8 1347-1360.

Seagroves TN, Lydon JP, Hovey RC, Vonderhaar BK \& Rosen JM $2000 \mathrm{C} / \mathrm{EBPb}$ (CCAAT/enhancer binding protein) controls cell fate determination during mammary gland development. Molecular Endocrinology 14 359-368.

Shyamala G, Schneider W \& Schott D 1990 Developmental regulation of murine mammary progesterone receptor gene expression. Endocrinology 126 2882-2889.

Sivaraman L, Hilsenbeck SG, Zhong L, Gay J, Conneely OM, Medina D \& O'Malley BW 2001 Early exposure of the rat mammary gland to estrogen and progesterone blocks co-localization of estrogen receptor expression and proliferation. Journal of Endocrinology $17175-83$.

Soyal S, Ismail PM, Li J, Mulac-Jericevic B, Conneely OM \& Lydon JP 2002 Progesterone's role in mammary gland development and tumorigenesis as disclosed by experimental mouse genetics. Breast Cancer Research 4 191-196.

Tan J, Paria BC, Dey SK \& Das SK 1999 Differential uterine expression of estrogen and progesterone receptors correlates with uterine preparation for implantation and decidualization in the mouse. Endocrinology 140 5310-5321.

Tetel MJ, Giangrande PH, Leonhardt SA, McDonnell DP \& Edwards DP 1999 Hormone-dependent interaction between the amino- and carboxyl-terminal domains of progesterone receptor in vitro and in vivo. Molecular Endocrinology 13 910-924.

Tibbetts TA, Mendoza-Meneses M, O'Malley BW \& Conneely OM 1998 Mutual and intercompartmental regulation of estrogen recep- 
tor and progesterone receptor expression in the mouse uterus. Biology of Reproduction 59 1143-1152.

Tibbetts TA, DeMayo F, Rich S, Conneely OM \& O'Malley BW 1999 Progesterone receptors in the thymus are required for thymic involution during pregnancy and for normal fertility. PNAS 96 $12021-12026$.

Tora L, Gronemeyer H, Turcotte B, Gaub MP \& Chambon P 1988 The $\mathrm{N}$-terminal region of the chicken progesterone receptor specifies target gene activation. Nature 333 185-188.

Tsai M-J \& O'Malley BW 1991 Mechanisms of regulation of gene transcription by steroid receptors. In The Hormonal Control of Gene Expression, pp 101-116. Eds P Cohen \& JG Foulkes. Amsterdam: Elsevier Press.

Tsai M-J \& O'Malley BW 1994a Mechanism of Steroid Hormone Regulation of Gene Transcription. Molecular Biology intelligence unit, Austin, TX: RG Landes Co.

Tsai M-J \& O'Malley BW 1994b Molecular mechanisms of action of steroid/thyroid receptor superfamily members. Annual Review of Biochemistry 63 451-486.

Tsai SY, Carlsedt-Duke J, Weigel NL, Dahlman K, Gustafsson JA, Tsai MJ \& O'Malley BW 1988 Molecular interactions of steroid hormone receptor with its enhancer element: evidence for receptor dimer formation. Cell 55 361-369.
Vazquez F, Rodriguez-Manzaneque JC, Lydon JP, Edwards DP O'Malley BW \& Iruela-Arispe ML 1999 Progesterone regulates proliferation of endothelial cells. Journal of Biological Chemistry $2742185-2192$.

Vegeto E, Allan GF, Schrader WT, Tsai M-J, McDonnell DP \& O'Malley BW 1992 The mechanism of RU486 antagonism is dependent on the conformation of the carboxy-terminal tail of the human progesterone receptor. Cell $69703-713$.

Vegeto E, Shahbaz MM, Wen DX, Goldman ME, O'Malley BW \& McDonnell DP 1993 Human progesterone receptor A form is a cell and promoter specific repressor of human progesterone receptor B function. Molecular Endocrinology 7 1244-1255.

Webster NJ, Green S, Jin J \& Chambon P 1988 The hormone-binding domains of the estrogen and glucocorticoid receptors contain an inducible transcription activation function. Cell 54 199-207.

Weigel NL, Bai W, Zhang Y, Beck CA, Edwards DP \& Poletti A 1995 Phosphorylation and progesterone receptor function. Journal of Steroid Biochemistry and Molecular Biology 53 509-514.

Zhu Y, Bond J \& Thomas P 2003 Identification, classification and partial characterization of genes in humans and other vertebrates homologous to a fish membrane progestin receptor. PNAS $\mathbf{1 0 0}$ 2237-2242. 